\title{
IMPLEMENTASI TEKNIK PEMBELAJARAN KOLABORATIF DENGAN VARIASI MEDIA UNTUK PENINGKATAN HASIL BELAJAR DI SMPN 2 KALIJAMBE
}

\begin{abstract}
Abstrak
Penelitian ini bertujuan untuk: (1) meningkatkan hasil belajar kognitif dan kecenderungan berperilaku sesuai nilai target pembelajaran (peduli, kerja keras, disiplin, jujur, dan terbuka); (2) mengetahui kendalakendala dalam mengimplementasikan teknik pembelajaran kolaboratif dengan variasi media dan upaya mengatasinya. Subjek penelitian adalah siswa kelas VIII D SMP Negeri 2 Kalijambe Sragen tahun ajaran 2013/2014. Data yang diperoleh dari observasi, angket, tes, catatan lapangan, dan catatan harian guru, dianalisi secara kuantitatif dan kualitatif. Hasil penelitian menunjukkan bahwa: (1) implementasi teknik pembelajaran kolaboratif dengan variasi media dapat meningkatkan hasil belajar kognitif siswa kelas VIII D. Pada pratindakan nilai rata-rata kelas 45, ketuntasan klasikal 0\%. Di akhir siklus I, nilai rata-rata kelas dan ketuntasan klasikal masing-masing 64 dan 23,08\%. Akhir Siklus II, 71 dan 50\%. Sedangkan pada akhir siklus III, 77 dan 88,46\%. Demikian pula pada kecenderungan berperilaku sesuai nilai target pada siswa kelas VIII D terus mengalami peningkatan, (2) kendala yang dihadapi meliputi: kurang intensifnya pengorganisasian kelompok, dan lamanya waktu yang dibutuhkan guru untuk mempersiapkan pembelajaran. Untuk mengatasi kendala tersebut, guru membiasakan siswa berinteraksi secara positif dan bertanggung jawab dalam penyelesaian tugas kelompok, serta optimalisasi penggunaan waktu dalam mempersiapkan pembelajaran dengan memanfaatkan media informasi yang ada.
\end{abstract}

Kata Kunci: teknik pembelajaran kolaboratif, variasi media, hasil belajar.

\section{IMPLEMENTING A COLLABORATIVE LEARNING TECHNIQUE WITH A VARIETY OF MEDIA TO INCREASE THE LEARNING OUTCOMES IN SMPN 2 KALIJAMBE}

\author{
Nanik sulistyawati, Darmiyati Zuchdi \\ SMP Negeri 2 Kalijambe, Sragen, Universitas Negeri Yogyakarta \\ naniksulistyawati85@yahoo.com,darmiyatiz@yahoo.com
}

\begin{abstract}
This study aims to: (1) improve the social studies learning outcomes in the form of cognitive learning outcomes and a tendency to behave according to the value of the target learning (caring, work hard, decipline, honesty, and open attitude); and (2) reveal the constraints in implementing the collaborative learning technique with a variety of media and the efforts to overcome these constraints. The subjects were class VIII D students of SMP Negeri 2 Kalijambe, Sragen, in the academic year of 2013/2014. The data were collected through document reviews, observation, questionnaires, tests, field notes, and teacher's daily note, were analyzed using quantitative and qualitative techniques. The results show that: (1) the implementation the collaborative learning technique with a variety of media can improve the cognitive of learning outcomes of class VIII D students. In the pre-action, the class' average score is 45 with the classical completeness percentage being $0 \%$. In the end of first cycle, the class' average score and the classical completeness percentage each are 64 and 23.08\%, in the end of second cycle 71 and $50 \%$, and in the end of third cycle increased are 77 and $88.46 \%$. So is the case with the tendency to behave in accordance with the value of the learning targets always increased. (2) the contraints in encountered include the less intensive group organization and the long time required by teachers to prepare lessons. To fix this, teachers make students accustomed to interaction positivelly and to accoutability in accordance with their respective tasks in their peer groups, as well as optimizing the use of time to make lesson plans by utilizing the existing information media.
\end{abstract}

Keywords: collaborative learning technique, a variety of media, learning outcomes. 


\section{Pendahuluan}

Salah satu tujuan nasional bangsa Indonesia adalah mencerdaskan kehidupan bangsa. Untuk mewujudkan tujuan mulia tersebut, pemerintah mengusahakan dan menyelenggarakan satu sistem pendidikan nasional seperti yang tercantum dalam Undang-undang Nomer 20 Tahun 2003 tentang Sisdiknas. dikatakan bahwa pendidikan nasional diharapkan dapat mengembangkan potensi siswa, sehingga menjadi manusia yang berilmu, cakap, beriman, bertakwa kepada Tuhan Yang Maha Esa, serta berakhlak mulia. Dengan dmikian pendidikan nasional tidak hanya mengembangkan kemampuan siswa dari segi kognitif semata, melainkan juga segi moral dan spiritual. Pendidikan nasional harus dapat menyeimbangkan kebutuhan intelektual, moral, maupun spiritual.

Terkait dengan hal tersebut, pembelajaran IPS dirancang sedemikian rupa sehingga dapat membimbing dan merefleksikan kemampuan siswa dalam menjalani kehidupan baik di masyarakat, berbangsa dan bernegara yang selalu mengalami perubahan dan berkembang terus-menerus. Hal ini merupakan tantangan yang sangat berat, mengingat perubahan dan perkembangan setiap saat tersebut, menuntut pula perubahan dan perkembangan dalam penyelenggaraan pendidikan. Perubahan ini bukan hanya secara fisik (fasilitas pendidikan) tetapi meliputi juga sarana nonfisik seperti pengembangan kualitas tenaga pendidikan, yang meliputi pengetahuan, sikap, dan keterampilan untuk memanfaatkan fasilitas yang tersedia.

Dari hasil diskusi dengan guru IPS kelas VIII D SMP N 2 Kalijambe Sragen terungkap bahwa hasil belajar siswa masih rendah. Masih banyak siswa yang memperoleh nilai di bawah KKM yang telah ditentukan, yaitu sebesar 71 . Hal ini dikarenakan pembelajaran IPS masih belum melibatkan siswa secara aktif. Meskipun pembelajaran dengan cara kelompok sudah dilakukan, namun belum pernah menerapkan teknik pembelajaran kolaboratif. Siswa yang terlibat dalam kerja kelompok hanya sebagian, sementara sebagian yang lain hanya "numpang nama". Siswa kurang memiliki kepedulian sosial, tidak mau bekerja keras, tidak disiplin terhadap penyelesaian tugas kelompok, dan kurang terbuka dengan teman yang lain. Sering dijumpai bahwa dalam pelaksanaan ulangan harian, banyak siswa yang berperilaku tidak jujur dengan cara mencontek, atau meminta jawaban kepada siswa yang lain. Selain itu, penggunaan media yang bervariasi belum dilakukan guru.

Pemecahan masalah tersebut, tentu bukan pekerjaan yang mudah bagi guru. Diperlukan berbagai upaya untuk meningkatkan hasil belajar kognitif siswa dan kecenderungan untuk berperilaku sesuai dengan nilai yang relevan dengan pembelajaran dan berguna dalam berinteraksi sosial, meliputi nilai peduli, kerja keras, disiplin, jujur, dan terbuka. Sehubungan dengan kompleksnya permasalahan di kelas VIII D tersebut, maka peneliti terdorong untuk melakukan penelitian berjudul "Implementasi Teknik Pembelajaran Kolaboratif dengan Variasi Media untuk Peningkatan Hasil Belajar di SMP Negeri 2 Kalijambe, Sragen.

Dengan mengimplementasikan teknik pembelajaran kolaboratif yang menekankan pada kerjasama kelompok secara intensif, diharapkan siswa kelas VIII D dapat meningkatkatkan keterlibatan aktif mereka proses pembelajaran, menumbuhkan rasa saling peduli antarsiswa, mau bekerja keras, disiplin dalam penyelesaian tugas kelompok, jujur dan terbuka di antara sesama. Sehingga potensi dan kemampuan siswa dapat dikembangkan secara optimal.

Implementasi teknik pembelajaran kolaboratif dan variasi media, diharapkan rasa kepekaan dan kepedulian satu dengan yang lainnya pada siswa keas VIII D dapat meningkat, sehingga dapat terbangun kerjasama yang positif antar siswa dalam proses pembelajaran. Hal tersebut seperti yang terungkap dalam hasil penelitian yang dilakukan Singgih Santosa yang berjudul "Pengaruh Model Pembelajaran Kolaboratif Dan Motivasi Belajar Terhadap Peningkatan Hasil Belajar Fisika Siswa Kelas X SMA Negeri 1 Purwantoro Wonogiri, Jawa Tengah". Hasil penelitiannya membuktikan bahwa model pembelajaran kolaboratif dapat meningkatkan motivasi belajar dan hasil belajar fisika, dibandingkan dengan metode ceramah.

Penggunaan variasi media dalam pembelajaran, mengakibatkan interaksi antara guru dengan siswa dapat lebih lancar dan efisien. Dengan variasi media, perhatian siswa menjadi lebih meningkat. Siswa menjadi lebih termotivasi belajar, mendorong kemampuan berfikir, serta dapat meningkatkan kemampuan belajar mereka. 
Variasi media dapat mengatasi siswa yang kurang perhatian pada pelajaran, siswa menjadi tidak mudah mengantuk, dan tidak cepat bosan dalam belajar. Untuk itulah penggunaan variasi media dalam pembelajaran penting dilakukan guru agar pembelajaran menarik, sehingga dapat meningkatkan hasil belajar mereka.

Penelitian ini bertujuan untuk: (1) meningkatkan hasil belajar kognitif dan kecenderungan berperilaku sesuai nilai target pembelajaran (peduli, kerja keras, disiplin, jujur, dan terbuka) pada siswa klas VIII D, dan (2) mengetahui kendala-kendala dalam mengimplementasikan teknik pembelajaran kolaboratif dengan variasi media dan upaya mengatasinya.

Selama ini, dalam pembelajaran IPS, tipe hasil belajar kognitif lebih dominan daripada tipe hasil belajar yang lain. Hal ini dikarenakan pengukuran hasil belajar kognitif lebih mudah dilakukannya. Namun demikian, hasil belajar psikomotor, afektif, dan keterampilan sosial, tetap harus menjadi bagian dari penilaian hasil proses pembelajaran. Hasil belajar menurut Gagne, dibagi menjadi lima kategori, yang disebutnya sebagai five categories of learning outcomes (1978: pp.49-51) yakni: intellectual skills, cognitive strategies, verbal information, motor skills, attitudes. Selanjutnya, taksonomi Bloom yang telah dikembangkan oleh Dettmer (2006, p.70), hasil belajar diklasifikasikan menjadi 4 domain yaitu domain kognitif, afektif, psikomotorik, dan keterampilan sosial yang disebut sebagai Developing Human Potential in Four Domains for Learning and Doing.

Pembelajaran IPS berkait erat dengan penanaman karakter bangsa. Hal tersebut seperti yang dikemukakan Sardiman (Zuchdi, 2011, pp.392-393), bahwa pembelajaran IPS diharapkan dapat melahirkan warga negara yang baik, demokratis, kreatif, kritis, berkemampuan belajar, senang membaca, memiliki rasa ingin tahu, mampu melakukan komunikasi secara produktif dalam masyarakat, jujur, kasih sayang, tanggung jawab, peka dan empati terhadap lingkungan, toleransi, dan saling menghargai, santun, mandiri, dan berjiwa nasionalis. Dengan demikian, maka hasil belajar IPS yang ditekankan dalam penelitian ini adalah kemampuan yang merupakan hasil optimal siswa baik dalam aspek kognitif, maupun kecenderungan pada siswa untuk berperilaku sesuai dengan nilai-nilai yang berkembang dalam masyarakat dan dipilih sebagai target pembelajaran. Nilai yang dimaksud meliputi nilai peduli, kerja keras, disiplin, jujur, dan terbuka. Sehingga diharapkan siswa mampu mencapai hasil belajar kognitif yang maksimal sekaligus dapat berperilaku sebagai warga masyarakat yang baik.

Yang dimaksud dengan nilai (values) menurut Solihatin dan Rahardjo (2011, p.19), adalah keyakinan yang menjadi pegangan dan dilaksanakan serta dipelihara dari generasi ke generasi secara turun temurun. Sedangkan menurut Mulyana (1986, p.11), dikatakan bahwa nilai adalah rujukan maupun keyakinan dalam menentukan pilihan. Oleh karena itu, nilai dapat menjadi ciri atau karakteristik suatu masyarakat, artinya jika suatu masyarakat memiliki nilai, maka masyarakat tersebut akan berharga dalam pandangan orang, demikian berlaku sebaliknya.

Untuk menyadarkan siswa akan kebenaran, kebaikan, dan keindahan melalui proses pertimbangan nilai yang tepat dan pembiasaan siswa untuk bertindak secara konsisten, maka perlu adanya pendidikan nilai kepada para siswa. Seperti yang diutarakan oleh Mulyana, bahwa pendidikan nilai adalah pengajaran atau bimbingan kepada peserta didik agar menyadari kebenaran, kebaikan, dan keindahan melalui proses pertimbangan nilai yang tepat dan pembiasaan bertindak yang konsisten (1986, p.119).

Pendidikan nilai di sekolah, dapat dilakukan oleh para guru dengan jalan pengintegrasian pendidikan nilai melalui proses pembelajaran. Mengintegrasikan nilai dalam pembelajaran IPS penting dilakukan oleh para guru IPS. Seperti yang diungkapkan oleh Sulistyowati bahwa mengintegrasikan nilai-nilai budaya dan karakter bangsa pada setiap mata pelajaran bertujuan agar siswa sadar akan arti penting nilai-nilai, dan menginternalisasi nilai-nilai tersebut ke dalam perilaku siswa sehari-hari, baik di lingkungan sekolah maupun di masyarakat (2012, p.47).

Pengintegrasian pendidikan nilai dalam proses pembelajaran IPS ini dilakukan melalui tahap perencanaan, pelaksanaan sampai evaluasi pembelajaran, sesuai dengan langkah-langkah pengintegrasian pendidikan karakter pada Pendidikan Karakter di Sekolah Menengah Pertama tahun 2011. Untuk tahap perencanaan, 
baik silabus, RPP, maupun bahan ajar dirancang agar muatan maupun kegiatan pembelajarannya bersifat memfasilitasi atau berwawasan pendidikan nilai. Pada tahap pelaksanaan, kegiatan pembelajaran dipilih dan dilaksanakan agar siswa mempraktikkan (habituasi) nilai-nilai yang menjadi target pembelajaran. Akhirnya pada tahap evaluasi, teknik dan instrumen penilaian yang dipilih dan dilaksanakan tidak hanya mengukur pencapaian akademik/kognitif saja, namun juga mengukur perkembangan kepribadian siswa.

Penggunaan media dalam pembelajaran akan membantu siswa dalam menerima pesan pembelajaran seperti yang diutarakan oleh Gafur (2012, p.107), bahwa media pembelajaran berfungsi untuk mengatasi masalah-masalah komunikasi yang muncul dalam pembelajaran. Selain itu, media dapat membangkitkan rasa ingin tahu siswa; merangsang siswa bereaksi baik secara fisik maupun emosional (Solihatin dan Rahardjo, 2011, p.24). Apalagi jika media tersebut bervariasi, suasana belajar menjadi lebih hidup, menggembirakan, dan tidak membosankan. Menurut Djamarah (2010, p.169), bila guru melakukan penggunaan variasi media, akan memerlukan penyesuaian indra siswa, membuat perhatian siswa menjadi lebih tinggi, memberi motivasi untuk belajar, mendorong berfikir, meningkatkan kemampuan belajar, selanjutnya dapat meningkatkan hasil belajar siswa. Menggunakan variasi diartikan sebagai perbuatan guru dalam konteks proses pembelajaran dengan tujuan mengatasi kebosanan siswa, sehingga dalam proses belajar, siswa selalu menunjukkan ketekunan, keantusiasan, serta berperan secara aktif (Hasibuan, 1986, p.64).

Menurut Dillenbourgh (1999, p. 1), pembelajaran kolaboratif merupakan situasi di mana dua orang atau lebih belajar atau berusaha untuk belajar tentang sesuatu bersama-sama. Pembelajaran kolaboratif menuntut adanya saling ketergantungan yang positif, interaksi antarsiswa yang saling mendukung, tanggung jawab individual maupun kelompok, pengembangan keterampilan kerja tim, dan pemrosesan kegiatan kelompok (Barkley, 2012, pp.13-14). Dengan demikian. pembelajaran kolaboratif menjadikan pembelajaran lebih bermakna, mendorong siswa untuk bertanggung jawab terhadap pembelajaran, menjadi lebih kreatif, dan pada akhirnya dapat meningkatkan hasil belajar kognitif sesuai yang diharapkan. Seperti yang dinyatakan oleh Hari Srivinas, bahwa dengan pembelajaran kolaboratif, dapat menjangkau hasil pembelajaran yang tinggi baik bagi guru maupun siswa dan relevan bagi pengembangan nilai peduli, kerja keras, disiplin, jujur, dan terbuka yang menjadi target dalam pembelajaran (Warsono, 2012, p. 80).

Terdapat beberapa teori yang menjadi landasan bagi pembelajaran kolaboratif, di antaranya teori demokrasi dalam pendidikan yang dikembangkan oleh John Dewey, teori konstruktivisme sosial dari Lev Vygotsky, teori scaffolding dari Bruner, serta teori psikologi humanistik (Warsono, 2012, p.56). Dalam teori konstruktivisme sosial dari Lev Vygotsky. Lev Vygotsky, seorang psikolog dari Rusia, dirumuskan teori terkait psikologi sosial yang terkenal dengan nama zona perkembangan terdekat atau zone of proximal development, $Z P D$ (Budiningsih, 2012, p.101). Dalam teorinya, Vygotsky mengatakan bahwa pada pertumbuhan awal kognitif, seorang anak dapat melakukan penyelesaian tugas-tugas yang berhubungan dengan pembelajarannya tanpa bantuan orang lain. Namun pada level kognitif yang lebih tinggi, penyelesaian tugas pembelajaran harus dibantu orang lain yang lebih kompeten, misalnya teman sebaya, orang tua, dan guru. Wilayah dengan level kognitif yang lebih tinggi ini disebut $Z P D$. Dalam hal bantuan (assistance) dari orang lain yang lebih kompeten tersebut, artinya anak harus melakukan kontak sosial terlebih dahulu dan melakukan "kolaborasi" dengan pihak lain untuk mencapai tataran kognitif yang lebih tinggi.

Johnson \& Johnson (Barkley, E, et. al: 2012, pp.13-14), berpandangan bahwa paling tidak terdapat lima unsur dasar agar dalam suatu kelompok terjadi pembelajaran kolaboratif, yaitu: (1) saling ketergantungan positif, (2) interaksi langsung antar siswa, (3) pertanggungjawaban individu, (4) keterampilan berkolaborasi, (5) keefektifan proses kelompok. Siswa memproses keefektifan kelompok belajarnya dengan cara menjelaskan tindakan mana yang dapat menyumbang belajar dan mana tindakan yang tidak dapat memberikan sumbangan dalam belajar, serta membuat keputusan-keputusan tindakan yang dapat dilanjutkan atau yang perlu diubah. 
Ada banyak teknikatau carayang digunakan guru dalam mengimplementasikan pembelajaran kolaboratif (Barkley, E, et. al:, 2012, p.145). Dari sekian banyak teknik pembelajaran yang telah diimplementasikan dalam pembelajaran, secara ringkas, teknik pembelajaran kolaboratif digolongkan menjadi 5 macam kategori, yaitu: (1) diskusi, (2) pengajaran resiprokal oleh teman, (3) penyelesaian masalah, (4) mengelola informasi grafis, dan (5) menulis. Sedangkan, menurut Warsono (2012, pp. 81-130), terdapat beberapa teknik pembelajaran kolaboratif yang pernah dikembangkan oleh para ahli maupun praktisi pendidikan, di antaranya adalah: teknik pembelajaran sebaya (peer learning), teknik debat, teknik sel belajar (learning cell), teknik reaksi terhadap video (a reaction to video), teknik pengajaran berbalasan (reciprocal teaching), thinking aloud pair problem solving, teknik $P O E$ (predict-observe-explain), teknik PDEODE (predict-discuss-explain-observe-discussexplain), teknik POGIL (process-orientedguidede-inquiry learning), teknik 5 E (5Es technique), teknik KWLH (know-want-learnedhow), teknik pembelajaran pemandu grafis, teknik pembelajaran peta konsep, dan CSCL atau computer-supported-collaborative learning).

Dari berbagai teknik pembelajaran kolaboratif tersebut, dalam penelitian ini digunakan teknik pembelajaran kolaboratif Lima E (5 Es Technique). Langkah-langkah teknik $5 \mathrm{E}$ (5 Es technique) dalam pembelajaran kolaboratif seperti yang jelaskan oleh Warsono (2012, pp.100-105) adalah sebagai berikut:

\section{Engage (Libatkan)}

Pada tahap ini, pembelajaran bertumpu pada berbagai upaya untuk meningkatkan minat siswa sambil menilai pemahaman awal siswa terhadap materi yang akan dibahas.

\section{Exlpore (Eksplorasi)}

Pada tahapan ini, melalui kerja sama dengan kelompoknya, siswa mengalami pengalaman belajar bersama dengan saling berbagi dan berkomunikasi tentang esensi tema pembelajaran. Guru bertindak sebagai fasilitator yang menyediakan bahan-bahan pembelajaran yang diperlukan, memandu siswa untuk fokus dalam belajar, serta memberi kesempatan kepada siswa untuk membangun pemahamnnya sendiri.

\section{Explain (Jelaskan)}

Di tahap ini, siswa menjelaskan apa yang telah dipelajari selama proses pembelajaran kepada rekan-rekannya dengan dipandu guru sampai semua betul-betul memahami materi, dan tidak ada miskonsepsi di kalangan siswa, selanjutnya membuat ringkasan materi.

\section{Extend (Kembangkan)}

Siswa diberi kesempatan untuk mengaitkan materi dengan kejadian di dunia nyata. Selanjutnya siswa mengaplikasikan konsep yang telah terbentuk untuk menyelesaikan atau menganalisis permasalahan atau isu yang dikemukakan.

\section{Evaluate (Evaluasi)}

Para siswa maupun guru membuat penilaian tentang sejauh mana terjadi pembelajaran dan pemahaman tentang konsep-konsep pokok yang terkait dengan materi. Penilaian mencakup berbagai aspek yaitu penguasaan konsep, keterampilan proses, aplikasi konsep, kreativitas dan sikap yang diharapkan dapat mengasilkan tindakan nyata.

Mengimplelntasikan teknik pembelajaran kolaboratif 5 E yang didukung dengan penggunaan variasi media, menjadikan siswa lebih memahami materi pembelajaran. Dalam penelitiannya yang berjudul: Penerapan Media Pembelajaran Bervariasi dapat Meningkatkan Hasil Belajar IPA di SMP Negeri 40 Semarang, Izzun Nadlah (2011) memperoleh kesimpulan bahwa dengan melakukan pembelajaran yang ditunjang penggunaan variasi media ternyata dapat meningkatkan keberhasilan pembelajaran dan ketuntasan belajar.

Variasi media dalam penelitian ini berupa handout, puzzle, dan gambar-gambar yang terkait dengan masalah kependudukan dapat memberi positif terhadap siswa kelas VIII D. Pengaruh tersebut berupa peningkatan stimulasi terhadap indra siswa, oleh karenanya pembelajaran menjadi lebih konkrit dan realistis.

Oleh karena itu, implementasi teknik pembelajaran kolaboratif $5 \mathrm{E}$ dengan variasi media diharapkan dapat meningkatkan hasil belajar siswa baik dalam ranah kognitif maupun kecenderungan pada siswa untuk berperilaku sesuai nilai yang menjadi target pembelajaran. Selanjutnya pertanyaan penelitian yang dapat diajukan peneliti pada penelitian tindakan kelas 
ini adalah sebagai berikut: (1) Seberapa besar peningkatan hasil belajar IPS dalam ranah kognitif dan kecenderungan berperilaku sesuai dengan nilai-nilai yang menjadi target pembelajaran pada siswa kelas VIII D setelah dimplementasikan teknik pembelajaran kolaboratif dengan variasi media?; (2) Kendala-kendala apa sajakah yang dihadapi dalam mengimplementasikan teknik pembelajaran kolaboratif dengan variasi media dan bagaimana upaya mengatasi kendala tersebut?

\section{Metode Penelitian}

Jenis penelitian ini adalah penelitian tindakan kelas (classroom action research) untuk meningkatkan hasil belajar siswa kelas VIII D SMP Negeri 2 Kalijambe melalui implementasi teknik pebelajaran kolaboratif dengan variasi media. Model penelitian yang dipergunakan berbentuk siklus yang mengacu pada model Kemmis dan Mc Taggrat. Penelitian tindakan kelas digambarkan sebagai proses dinamis yang meliputi 4 komponen, yaitu perencanaan, tindakan, pengamatan, dan refleksi yang terus berulang sampai tujuan penelitian tercapai.

Penelitian ini dilaksanakan pada bulan September sampai dengan bulan Desember 2013. Pengambilan data penelitian dilakukan pada bulan September sampai dengan bulan Oktober 2013. Penelitian dilaksanakan secara alami sejalan dengan proses pembelajaran yang berlangsung di kelas, yaitu 4 jam pelajaran dalam satu minggu yang dilaksanakan dalam dua kali pertemuan@40 menit.

Subjek penelitian ini adalah siswa kelas VIII D SMP Negeri 2 Kecamatan Kalijambe Kabupaten Sragen tahun pelajaran 2013/2014 yang berjumlah 26 orang. Alasan dipilihnya kelas VIII D adalah karena di kelas tersebut hasil belajar IPS sangat rendah, yaitu rata-rata hasil ulangan harian siswa kelas VIII D pada materi Kondisi Fisik, Wilayah, dan Penduduk Indonesia adalah 64 dengan prosentase ketuntasan klasikal sebesar $43,90 \%$. Atau dikatakan $66,10 \%$ siswa belum lulus dari kriteria ketuntasan minimal yang ditetapkan sebesar 71. Selain itu, dari hasil diskusi peneliti dengan guru IPS kelas VIII D, terungkap bahwa kecenderungan siswa kelas VIII D untuk berperilaku peduli, kerja keras, disiplin, jujur, dan terbuka yang menjadi target pembelajaran tergolong masih rendah.

Penelitian Tindakan Kelas lakukan dengan mengimplementasikan teknik pembelajaran kolaboratif dengan variasi media pada siswa kelas VIII D Semester 1 SMP N 2 Kalijambe Sragen. Prosedur penelitian tindakan kelas dilaksanakan secara siklis yang berlangsung secara berkesinambungan sesuai model Kemmis \& Taggart sampai tercapai target keberhasilan penelitian yaitu:

Pertama, Adanya peningkatan hasil belajar kognitif siswa dalam pembelajaran IPS. Indikator hasil belajar kognitif dapat dilihat dari siswa di kelas VIII D yang telah mencapai nilai Kriteria Ketuntasan Minimal $(\mathrm{KKM}) \geq 71$ sebesar $75 \%$ dari 26 siswa.

Kedua, Adanya peningkatan hasil belajar yang berupa kecenderungan perilaku yang sesuai dengan nilai target pembelajaran pada siswa kelas VIII D. Indikator mengenai kecenderungan perilaku yang sesuai dengan nilai target pada siswa kelas VIII D, dapat dilihat dari banyaknya siswa yang berada pada kategori baik, paling sedikit $75 \%$ dari 26 siswa.

Pada setiap siklus, dilakukan dengan menggunakan langkah-langkah sebagai berikut:

Perencanaan (Planning).

Pada tahap perencanaan, kegiatan yang dilakukan meliputi: (1) membuat perencanaan pembelajaran yang mengacu pada temuantemuan kondisi awal pra-penelitian. Melakukan koordinasi dengan kolaborator yakni guru IPS kelas VIII D, (2) menyiapkan perangkat pembelajaran, (3)menyiapkan media, sumber dan alat pembelajaran seperti puzzle, gambargambar visual yang terkait dengan materi, $L C D$, laptop, serta buku-buku penunjang proses pembelajaran dan perangkat pendukung lainnya, (4) menyiapkan instrumen pengumpulan data.

\section{Pelaksanaan Tindakan (Action)}

Pada tahap tindakan, kolabolator melakukan tindakan dan peneliti melakukan pengamatan. Penelitian ini menggunakan desain teknik pembelajaran kolaboratif 5 E (5 Es Technique) dengan menggunakan variasi media yang tahapan-tahapan tindakannya sebagai berikut: 
Tabel 1. Kegiatan Teknik Pembelajaran Kolaboratif 5 E dengan Variasi Media

\begin{tabular}{|l|l|l|}
\hline $\begin{array}{l}\text { Langkah-langkah } \\
\text { Pembelajaran }\end{array}$ & Tahapan & Kegiatan \\
\hline Pendahuluan & 1. Engage & $\begin{array}{l}\text { Guru mengawali kegiatan dengan salam pembuka dan berdo'a } \\
\text { Guru memeriksa kehadiran siswa, kebersihan dan kerapihan } \\
\text { kelas } \\
\text { Guru menggali hubungan materi sebelumnya dengan materi } \\
\text { yang akan dipelajari. } \\
\text { Guru dan siswa menetukan tujuan pembelajaran. }\end{array}$ \\
\hline \multirow{5}{*}{ Kegiatan Inti } & 2. Explore & $\begin{array}{l}\text { Siswa dibagi menjadi 5 kelompok secara heterogen } \\
\text { Guru membimbing dan menjelaskan peran setiap anggota } \\
\text { kelompok untuk kesuksesan kerja kelompok/tim } \\
\text { Guru membagi materi untuk dipelajari bersama-sama. }\end{array}$ \\
\cline { 2 - 4 } & 3. Explain & $\begin{array}{l}\text { Guru membagi tugas yang dikemas dalam suatu puzzle } \\
\text { Guru memfasilitasi siswa untuk terlibat secara langsung } \\
\text { dalam kerja tim dalam memecahkan tugas kelompok. } \\
\text { Guru memfasilitasi terjadinya interaksi antar masing-masing } \\
\text { anggota kelompok selama diskusi berlangsung. } \\
\text { Presentasi hasil diskusi kelompok.. } \\
\text { Guru meluruskan miskonsepsi siswa }\end{array}$ \\
\hline & 4. Extend & $\begin{array}{l}\text { Guru mempersilahkan siswa untuk bertanya apabila belum } \\
\text { paham } \\
\text { Guru memberikan penguatan } \\
\text { Guru memberikan umpan balik } \\
\text { Guru mengingatkan siswa untuk selalu belajar dengan } \\
\text { mengembangkan sikap teliti, kreatif dan bertanggung jawab }\end{array}$ \\
\hline & $\begin{array}{l}\text { Memberikan pertanyaan lisan } \\
\text { Melakukan observasi pembelajaran } \\
\text { Memberikan tes hasil belajar } \\
\text { Memberikan penilaian tes hasil belajar }\end{array}$ \\
\hline
\end{tabular}

Observasi (Observation)

Pada tahap ini peneliti melakukan pengamatan proses pembelajaran dengan menggunakan lembar observasi yang telah dipersiapkan.

\section{Refleksi (Reflection)}

Kegiatan refleksi digunakan peneliti untuk mengkaji mengenai apa yang telah dilakukan, apa yang telah dihasilkan, apa yang belum dihasilkan, serta kendala apa yang dihadapi selama tindakan untuk melakukan perbaikan pada tindakan berikutnya. Pada tahapan ini, peneliti bersama kolaborator mengadakan evaluasi dan refleksi berkaitan dengan kegiatan pembelajaran yang sudah dilakukan. Kegiatan refleksi meliputi semua kegiatan dari tahapan perencanaan, pelaksanaan tindakan, dan observasi yang sudah dilakukan.
Teknik dan instrumen pengumpulan data yang digunakan dalam penelitian ini adalah:

Observasi

Observasi atau pengamatan dalam penelitian ini digunakan untuk merekam kecenderungan siswa kelas VIII D dalam berperilaku peduli, kerja keras, jujur, disiplin, dan terbuka yang menjadi target pembelajaran. Observasi juga dilakukan untuk merekam proses pembelajaran yang dilakukan guru selama penelitian berlangsung.

\section{Catatan Lapangan}

Dalam penelitian ini, catatan lapangan digunakan untuk mencatat segala kejadian yang terjadi selama dilakukannya tindakan (action). 


\section{Catatan Harian Guru}

Dalam penelitian ini, catatan harian guru digunakan untuk mendapatkan data tentang hambatan yang dihadapi guru dalam mengimplementasikan teknik pembelajaran kolaboratif 5 E dengan variasi media, dn bahan refleksi untuk proses pembelajaran pada siklus berikutnya.

Dokumentasi

Dokumentasi dalam penelitian ini digunakan untuk mengumpulkan semua catatan penting yang berhubungan dengan penelitian seperti, lembar observasi kecenderungan siswa dalam berperilaku sesuai dengan nilai yang menjadi target pembelajaran, hasil pekerjaan siswa, hasil belajar siswa, daftar hadir siswa serta foto-foto.

\section{Tes}

Tes dilakukan untuk mendapatkan data tentang hasil belajar pada aspek kognitif. Tes diberikan kepada siswa dalam bentuk pilihan ganda dengan jumlah butir sebanyak 20 . Instrumen yang digunakan adalah lembar tes. Kisi-kisi tes tiap siklus dibuat berdasarkan Standar Kompetensi, Kompetensi Dasar dan Indikator.

\section{Kuisioner atau Angket}

Angket yang berisi serangkaian pertanyaan tertulis dan memerlukan jawaban tertulis dalam penelitian ini digunakan untuk melihat kecenderungan perilaku siswa sesuai dengan nilai target pembelajara sebelum dan setelah dilakukan tindakan. Lembar angket yang dipersiapkan adalah angket untuk siswa berisi pertanyaan untuk menggali informasi tentang kecenderungan siswa untuk berperilaku sesuai dengan nilai target dalam pembelajaran IPS. Instrumen angket dalam penelitian ini menggunakan daftar pertanyaan yang harus dijawab siswa sesuai dengan prinsip yang diyakininya dengan cara melingkari nomer yang sesuai. Semakin banyak skor yang diperoleh siswa, maka kecenderungan siswa untuk berperilaku sesuai dengan nilai yang menjadi target pada pembelajaran semakin baik, demikian sebaliknya.

Data yang diperoleh dalam penelitian selanjutnya dianalisis dengan menggunakan teknik analisis data kuantitatif dan kualitatif. Analisis kuantitatif dilakukan terhadap data hasil belajar kognitif dan kecenderungan berperilaku sesuai nilai yang menjadi target pembelajaran pada siswa kelas VIII D. Sedangkan analisis kualitatif dilakukan terhadap hasil penelitian terkait dengan kendala-kendala yang dihadapi dalam mengimplementasikan teknik pembelajaran kolaboratif 5 E dengan variasi media dan upaya mengatasinya.

Penilaian terhadap hasil belajar kognitif diperoleh dari hasil tes, yang selanjutnya dianalisis dengan rumus:

25

$$
21
$$

Untuk menghitung persentase ketuntasan belajar kelas digunakan rumus sebagai berikut:

Ketuntasan Belajar Klasikal

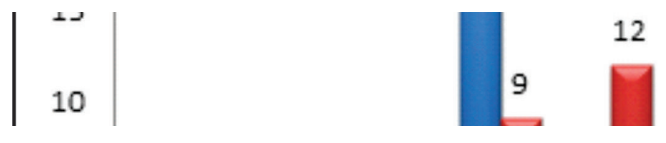

Data yang diperoleh melalui observasi maupun angket dianalisis menggunakan analisis kuantitatif. Jumlah butir instrumen observasi ada 5 dengan skor yang diberikan antara 1 sampai 4 . Penskoran yang digunakan dalam pengamatan kecenderungan berperilaku sesuai dengan nilai target pembelajaran menggunakan skala Likert, dengan kriteria: (1) Tidak pernah; (2) Kadangkadang; (3) Sering; dan (4) Sangat sering. Dengan demikian, skor ideal terendah 1 X $5=5$ dan skor ideal tertinggi 4 X $5=20$. Sedangkan pada instrumen angket dalam penelitian ini terdapat 21 butir pernyataan dengan menggunakan skala Likert yang dimodifikasi dengan 5 alternatif jawaban. Jawaban ditulis dengan melingkari nomer yang telah disediakan, yaitu (SS) untuk jawaban Sangat Setuju, (S) untuk jawaban Setuju, (KS) untuk jawaban Kurang Setuju, (TS) untuk jawaban Tidak Setuju, dan (STS) untuk jawaban Sangat Tidak Setuju.

Penelitian ini dinyatakan berhasil apabila tindakan yang dilakukan mencapai kriteria yang telah ditentukan. Adapun kriteria yang ditentukan untuk mengukur keberhasilan tindakan adalah sebagai berikut: (a) Adanya peningkatan hasil belajar kognitif siswa dalam pembelajaran IPS. Indikator hasil belajar kognitif dapat dilihat dari siswa di kelas VIII D yang telah mencapai nilai Kriteria Ketuntasan Minimal (KKM) $\geq 71$ sebesar 75\% dari 26 siswa; (b) Adanya peningkatan hasil belajar yang berupa kecenderungan perilaku yang sesuai dengan nilai target pembelajaran 
pada siswa kelas VIII D. Indikator mengenai kecenderungan perilaku yang sesuai dengan nilai target pada siswa kelas VIII D, dapat dilihat dari banyaknya siswa yang berada pada kategori baik, paling sedikit $75 \%$ dari 26 siswa.

Hasil Penelitian dan Pembahasan

Dari penelitian yang dilaksanakan melalui implementasi teknik pembelajaran kolaboratif dengan variasi media selama tiga siklus, dapat dipaparkan hasilnya sebagai berikut:

\section{Hasil belajar kognitif siswa kelas VIII D}

Data hasil belajar kognitif yang diperoleh dari hasil tes, memperlihatkan adanya peningkatan di setiap siklusnya seperti yang tersaji pada tabel 2 .

Tabel 2. Data Peningkatan Hasil Belajar Ranah Kognitif Siswa Kelas VIII D

\begin{tabular}{|c|c|c|c|c|c|c|c|c|c|}
\hline \multirow{2}{*}{ No } & \multirow{2}{*}{ Interval Nilai } & \multicolumn{2}{|c|}{ Pratindakan } & \multicolumn{2}{c|}{ Siklus I } & \multicolumn{2}{c|}{ Siklus II } & \multicolumn{2}{c|}{ Siklus III } \\
& & $\mathrm{f}$ & $\%$ & $\mathrm{f}$ & $\%$ & $\mathrm{f}$ & $\%$ & $\mathrm{f}$ & $\%$ \\
\hline $\mathbf{1}$ & $86-100$ & - & - & - & - & - & - & 2 & 8 \\
\hline 2 & $71-85$ & - & - & 6 & 23 & 13 & 50 & 21 & 81 \\
\hline 3 & $56-70$ & 5 & 19 & 11 & 42 & 11 & 42 & 3 & 11 \\
\hline 4 & $41-55$ & 9 & 35 & 9 & 35 & 2 & 8 & - & - \\
\hline 5 & $<40$ & 12 & 46 & - & - & - & - & - & - \\
\hline \multicolumn{2}{|c|}{ Jumlah } & 26 & 100 & 26 & 100 & 26 & 100 & 26 & 100 \\
\hline
\end{tabular}

Dari tabel di atas dapat dibuat grafik peningkatan dari pratindakan, siklus I, siklus II, sampai ke siklus III dapat dilihat pada gambar 1 .

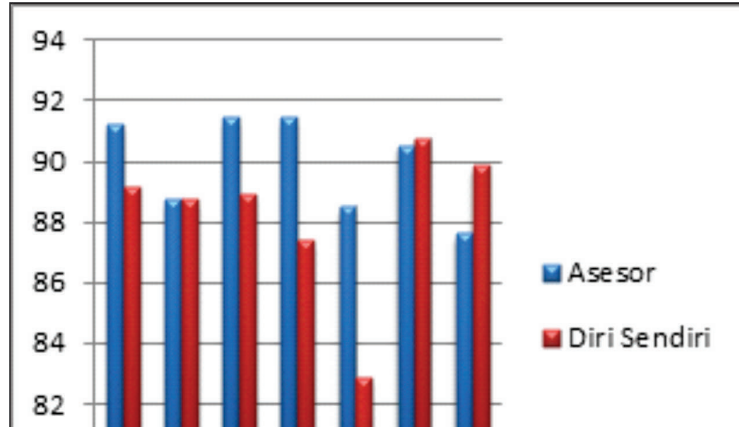

Gambar 1. Grafik Peningkatan Hasil Belajar Kognitif Siswa

Dengan mengimplementasikankan teknik pembelajaran kolaboratif $5 \mathrm{E}$ dan variasi media, rasa kepekaan dan kepedulian satu dengan yang lainnya pada siswa keas VIII D dapat meningkat, sehingga dapat terbangun kerjasama yang positif antar siswa dalam proses pembelajaran. Hal tersebut seperti yang diungkapkan Barkley (2012, p.4), bahwa pembelajaran kolaboratif berarti belajar melalui kerja kelompok yang penuh makna, bukan belajar dengan kerja sendirian.

Penerapan teknik pembelajaran kolaboratif 5 E yang didukung dengan penggunaan variasi media, menjadikan siswa lebih memahami materi pembelajaran. Variasi media dalam penelitian ini berupa handout, puzzle, dan gambar-gambar yang terkait dengan masalah kependudukan dapat memberi pengaruh positif terhadap siswa kelas VIII D. Pengaruh tersebut berupa peningkatan stimulasi terhadap indra siswa, oleh karenanya pembelajaran menjadi lebih konkrit dan realistis. Seperti yang diungkapkan oleh Djamarah (2010, p.169), bahwa apabila guru melakukan penggunaan variasi media, perhatian siswa menjadi lebih tinggi, lebih termotivasi untuk belajar, mendorong berfikir, dan meningkatkan kemampuan belajar. Dengan demikian, variasi media dapat meningkatkan peran aktif siswa dalam pembelajaran, yang pada akhirnya dapat menyebabkan adanya peningkatan hasil belajar siswa kelas VIII D.

Hasil Belajar Siswa VIII D Berupa Kecenderungan Berperilaku Sesuai Nilai Target Pembelajaran

Implementasi teknik pembelajaran kolaboratif $5 \mathrm{E}$ juga terbukti dapat memperkuat kecenderungan berperilaku sesuai nilai target pada siswa kelas VIII D. "Nilai" merupakan fondasi penting dalam menentukan karakter suatu masyarakat dan bangsa. Nilai dapat ditumbuhkan melalui proses pembelajaran di sekolah seperti yang diutarakan oleh Amborise dalam Mulyana (2004, p.23), bahwa nilai itu bersifat relatif dan menjadi landasan bagi perubahan. Nilai dapat ditanamkan melalui berbagai sumber seperti 
keluarga, masyarakat, agama, media massa, tradisi, pergaulan, termasuk pendidikan di sekolah.

Dengan pembelajaran kolaboratif, siswa kelas VIII D terlibat dalam aktivitas pembelajaran yang mengutamakan kerja tim secara terbuka, kerja keras, jujur, disiplin, dan peduli untuk mencapai tujuan pembelajaran yang ditetapkan. Bahkan penamaan kelompok atau tim siswa sesuai dengan nilai yang menjadi target pembelajaran. Dengan proses pembelajaran yang terus menekankan pada upaya penanaman nilai target, interaksi antarsiswa yang saling mendukung, tanggung jawab individual maupun kelompok, pengembangan keterampilan kerjatim, dan pemrosesan kegiatan kelompok maka pada siklus I, siklus II, dan siklus III kecenderungan berperilaku sesuai nilai target pada siswa kelas VIII D mengalami peningkatan ke arah yang lebih baik. Secara klasikal, persentase siswa kelas VIII D yang cenderung berperilaku sesuai nilai target dengan kategori minimal baik terus meningkat. Berdasarkan observasi yang dlakukan selama penelitian, siswa yang berperilaku baik terus meningkat dari $9 \%$ pada pratindakan, menjadi $28 \%$ pada akhir siklus I; $77 \%$ pada akhir siklus II; dan $88 \%$ pada akhir siklus III, seperti yang terlihat pada gambar 1 .

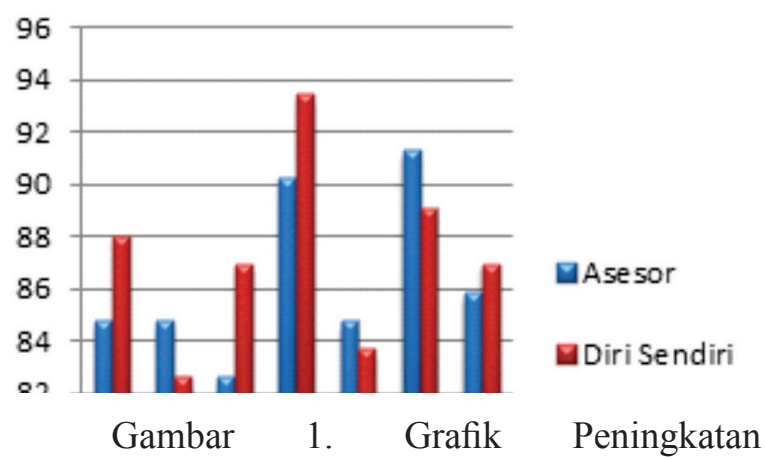

Kecenderungan Perilaku Siswa Sesuai Nilai Target Pembelajaran berdasarkan Hasil Observasi

Hasil tersebut diperkuat dengan data yang diperoleh dari angket yang dibagikan kepada siswa, seperti terlihat pada gambar 2 .

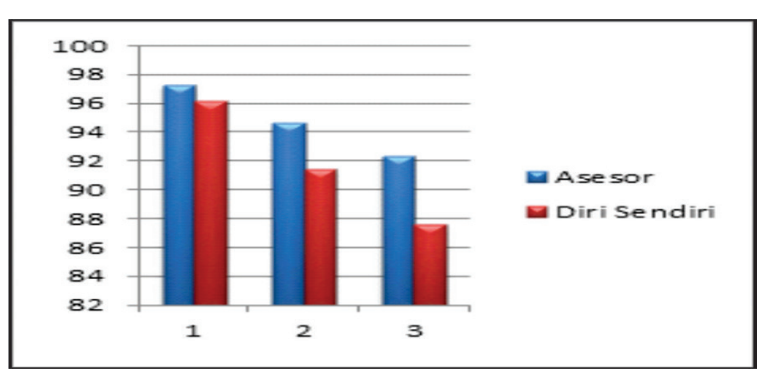

Gambar 2 Grafik Peningkatan Kecenderungan Perilaku Siswa Sesuai Nilai Target Pembelajaran Berdasarkan Hasil Angket

Berdasarkan data yang diperoleh dari angket, terlihat bahwa terjadi peningkatan persentase siswa yang berperilaku sesuai nilai target. Dari $58 \%$ pada pra tindakan, meningkat menjadi $73 \%$ pada akhir siklus I, $85 \%$ pada akhir siklus II. Dan pada akhir siklus III meningkat lagi menjadi 92\%. Dengan demikian hampir seluruh siswa kelas VIII D cenderung berperilaku peduli, mau bekerja keras, disiplin, jujur, dan terbuka dengan teman yang lain. Ini berarti, implementasi teknik pembelajaran kolaboratif dengan variasi media berpengaruh positif terhadap kecenderungan siswa kelas VIII D untuk berperilaku sesuai dengan nilai target.

Kendala-kendala yang dihadapi dalam mengimplementasikan teknik pembelajaran kolaboratif dengan variasi media dan upaya mengatasinya adalah sebagai berikut:

Kemampuan dalam Mengorganisir Kelompok Kurang Intensif

Kemampuan dalam mengorganisir kelompok yang kurang intensif ini dikarenakan adanya sifat-sifat pribadi yang ingin menonjolkan diri atau sebaliknya yang lemah merasa rendah diri dan selalu tergantung pada orang lain. Kebiasaan lama dalam berdiskusi kelompok dengan hanya "numpang nama" sulit dihilangkan. Sebagian siswa beraktivitas secara asal-asalan karena akan dengan mudah mengandalkan teman atau kelompok.

Untuk mengatasi hal tersebut, guru membiasakan pengorganisasian proses kerja kolaborasi dalam kelompok siswa. Kepada para siswa perlu dijelaskan tentang bagaimana penerapan prinsip-prinsip pembelajaran kolaboratif agar tercipta interaksi yang saling mendukung antar siswa dalam kelompoknya dan terlibat secara aktif selama proses pembelajaran. Selanjutnya siswa juga perlu dijelaskan bahwa keterampilan kerjasama akan membuahkan implikasi adanya keterampilan sosial yang dibutuhkan untuk berkolaborasi.

Keterampilan kerjasama berfungsi memperlancar hubungan kerja dan tugas. Sehingga tidak ada lagi siswa yang hanya beraktivitas asal-asalan dan hanya sekedar "numpang nama". Peranan hubungan kerja dapat 
dibangun dengan mengembangkan komunikasi antaranggota kelompok, mengembangkan kepedulian antarsiswa, dan mau bekerja keras dalam menyelesaikan tugas-tugas kelompok.

Waktu yang dibutuhkan guru dalam mempersiapkan variasi media dalam pembelajaran menjadi lebih lama

Dalam mempersiapkan media yang bervariasi tentu butuh waktu yang lama dan dituntut keseriusan. Apalagi harus mengaitkan dengan materi tentang kependudukan yang penting bagi para siswa untuk mengetahuinya, terutama tentang program kependudukan yang tengah dijalankan pemerintah. Berkaitan dengan kendala tersebut, guru dituntut cerdas dalam mengatur penggunaan waktu. Di samping itu, guru dituntut untuk selalu mengikuti perkmbangan informasi tentang kependudukan dengan memanfaatkan media informasi yang ada.

\section{Simpulan dan Saran}

Simpulan

Implementasi teknik pembelajaran kolaboratif dengan variasi media dapat meningkatkan hasil belajar IPS siswa kelas VIII D SMP Negeri 2 Kalijambe, baik dalam ranah kognitif maupun kecenderungan untuk berperilaku sesuai dengan nilai yang menjadi target pembelajaran.

Kendala yang dihadapai dalam mengimplementasikan teknik pembelajaran kolaboratif dengan variasi media berupa: (a) kemampuan siswa dalam mengorganisasi kelompok kurang intensif. Untuk mengatasinya, guru melakukan pembiasaan pengorganisasian proses kerja kolaborasi dalam kelompok siswa dengan menunjukkan sikap peduli dan mau bekerja keras. Selain itu, guru perlu menjelaskan tentang bagaimana penerapan prinsip-prinsip pembelajaran kolaboratif agar tercipta interaksi yang saling mendukung antarsiswa dalam kelompoknya dan terlibat secara aktif selama proses pembelajaran; (b) Waktu yang dibutuhkan guru dalam mempersiapkan pengadaan variasi media adalah lama. Untuk mengatasi kendala ini, guru perlu mengoptimalkan penggunaan waktu dalam mempersiapkan perangkat pembelajaran melalui pemanfaatan sarana dan prasarana yang ada di sekolah maupun media informasi yang sekarang sudah sangat canggih.
Saran

Melalui implementasi teknik pembelajaran kolaboratif dengan variasi media pada pembelajaran IPS, diharapkan guru dapat menggugah dan mengokohkan ke dalam diri siswa nilai-nilai kepedulian, kerja keras, disiplin, jujur, dan terbuka sebagai bekal siswa dalam mengarungi kehidupan sosial mereka.

Implementasi teknik pembelajaran kolaboratif dengan variasi media dalam proses pembelajaran IPS hendaknya dapat dikembangkan lebih lanjut dalam rangka meningkatkan hasil belajar siswa.

Implementasi teknik pembelajaran kolaboratif dengan variasi media dalam pembelajaran IPS sebaiknya disiapkan secara matang, sehingga proses maupun hasilnya lebih baik dan optimal. Implementasi teknik pembelajaran kolaboratif dengan variasi media dalam pembelajaran IPS sebaiknya disertai dengan pembiasaan pengorganisasian proses kerja kolaborasi dalam kelompok siswa dengan menunjukkan sikap peduli, mau bekerja keras, jujur, disiplin, dan terbuka

\section{Daftar Pustaka}

Barkley, E. E., et. al. (2012). Collaborative learning techniques (Teknik-teknik pembelajaran kolaboratif). (Terjemahan Narulita Yusron). Bandung: Penerbit Nusa Media

Budiningsih, C. A. (2012). Belajar dan pembelajaran. Jakarta: PT. Rineka Cipta

Dettmer, P. (2006). New bloom in established fields: four domains of learning and doing. Rooper Review, 28, 70-79

Dillenbourg, P. (1999). What do yuo mean by collaborative leraning?. In P. Dillenbourg (Ed). Collaborative-learning: cognitive and computational approaches. (pp.1-19). Oxford: Elsevier diakses tanggal Pada 17 Januari 2014 dari halshs.archives-ouvertes. $\mathrm{fr} / . . . / \mathrm{PDF} /$ Dillenbourg-Pi.

Djamarah, S. B. \& Zain, A. (2010). Strategi belajar mengajar . Jakarta : Rineka Cipta.

Gafur, A. (2012). Desain pembelajaran: konsep, model, dan aplikasinya dalam perencanaan pelaksanaan pembelajaran. Yogyakarta: Ombak 
Gagne,R.M \& Leslie J. B.(1978). Principles of instructional design. Second edition, New york: hott, Rinenart and Winston

Hasibuan. (1986). Proses belajar mengajar. Bandung: PT Remaja Rosdakarya.

Kebijakan Nasional Pembangunan Karakter Bangsa 2010-2025

Kemmis, S. \& Mc Taggart, R. (1990). The action research planner. Burwood: Deakin University Press.

Mulyana. (2004). Mengartikulasikan pendidikan nilai. Bandung: Alfabeta

Nadlah, I. (2011). Penerapan media pembelajaran bervariasi dapat meningkatkan hasil belajar IPA di SMP Negeri 40 Semarang. Jurnal Penelitian Pendidikan Unnes Nomer, 28, 48-53

Pendidikan Karakter di Sekolah Menengah Pertama. (2011)
Santosa, S. (2013). Pengaruh model pembelajaran kolaboratif dan motivasi belajar terhadap peningkatan hasil belajar fisika siswa kelas X SMA Negeri 1 Purwantoro Wonogiri, Jawa Tengah. Jurnal Berkala Fisika Indonesia, 5, 15-19

Solihatin, E. \& Raharjo, (2011), Cooperative learning (Analisis model pembelajaran). Jakarta: Bumi Aksara

Sulistyowati, E. (2012). Implementasi kurikulum pendidikan karakter. Yogyakarta: PT Citra Adi Parama

Undang-Undang No. 20 Tahun 2003 Tentang Sisdiknas

Warsono \& Hariyanto. (2012). Pembelajaran aktif, teori dan asesmen. Bandung: PT Remaja Rosdakarya

Zuchdi, D., Ed. (2011). Pendidikan karakter dalam perspektif teori dan praktik. Yogyakarta: UNY Press. 